\title{
To License or Not To License Updated: An Examination of State Statutes Regarding Private Investigators and Digital Examiners
}

Thomas Lonardo

Roger Williams University

Doug White

Roger Williams University

Alan Rea

Western Michigan University

Follow this and additional works at: https://commons.erau.edu/jdfsl

Part of the Computer Engineering Commons, Computer Law Commons, Electrical and Computer Engineering Commons, Forensic Science and Technology Commons, and the Information Security Commons

\section{Recommended Citation}

Lonardo, Thomas; White, Doug; and Rea, Alan (2012) "To License or Not To License Updated: An Examination of State Statutes Regarding Private Investigators and Digital Examiners," Journal of Digital Forensics, Security and Law. Vol. 7 : No. 3 , Article 5.

DOI: https://doi.org/10.15394/jdfsl.2012.1129

Available at: https://commons.erau.edu/jdfsl/vol7/iss3/5

This Article is brought to you for free and open access by

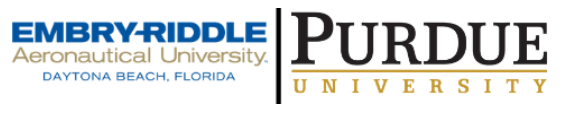
the Journals at Scholarly Commons. It has been accepted for inclusion in Journal of Digital Forensics, Security and Law by an authorized administrator of Scholarly Commons. For more information, please contact commons@erau.edu.

(c)ADFSL 


\title{
TO LICENSE OR NOT TO LICENSE UPDATED: AN EXAMINATION OF STATE STATUTES REGARDING PRIVATE INVESTIGATORS AND DIGITAL EXAMINERS
}

\author{
Thomas Lonardo \\ Gabelli College of Business \\ Roger Williams University \\ One Old Ferry Road \\ Bristol, RI 02809 \\ Phone: 401-254-3580 \\ E-mail: tlonardo@rwu.edu \\ Doug White \\ FANS Center, School of Justice Studies \\ Roger Williams University \\ One Old Ferry Road \\ Bristol, RI 02809 \\ Phone: 401-254-3165 \\ E-mail: dwhite@rwu.edu
}

\begin{abstract}
Alan Rea
Haworth College of Business

Western Michigan University

1903 West Michigan Avenue

Kalamazoo, MI 49008-5412

Phone: 269-387-1444

E-mailalan.rea@wmich.edu
\end{abstract}

\begin{abstract}
In this update to the 2009 year's study, the authors examine statutes that regulate, license, and enforce investigative functions in each US state. After identification and review of Private Investigator licensing requirements, the authors find that very few state statutes explicitly differentiate between Private Investigators and Digital Examiners, but do see a trend of more states making some distinction. The authors contacted all state regulatory agencies where statutory language was not explicit, and as a result, set forth the various state approaches to professional Digital Examiner licensing. As was the case in the previous two iterations of this research, the authors conclude that states must differentiate between Private
\end{abstract}


Investigator and Digital Examiner licensing requirements and oversight.

Keywords: Digital Examiner, Computer Forensics, State Statutes, Private Investigator, Licensing Requirements

\section{INTRODUCTION}

\subsection{Historical Background}

In the United States (US), state statutes set the guidelines for identification, oversight, and licensing of various investigative functions. Many years ago some states passed legislation to manage commercial police and security specialists who undertook roles similar to officers of the court, but neither no longer, nor ever had, held badges. In most statutes these individuals are identified as Private Detectives, Private Investigators (PI), or security officers.

However, these state statutes were defined in a period when not all areas of highly technical investigation, such as Digital Examiners and Computer Forensics existed. Hence, we see confusion among state statutes and the role of these new investigative professionals. For example, many statutes commonly define all investigators as "someone who attempts to prove the truth or falsity of a statement." Unfortunately, this language is so broad that it provides the opportunity for the inclusion of virtually any investigative profession, including Digital Examiners (DE), who routinely examines systems and media to provide investigative evidence. This situation is problematic for all involved. Some states, such as Texas, have gone so far as to interpret investigation to include computer technicians and computer repair personnel (Kramer, 2009). This situation may complicate and prevent individuals from working, as they may not be able to obtain the license given the requirements of that state.

Many organizations continue to address this disconnect between statutes and new forms of digital and computer forensic investigation. The American Bar Association issued an opinion in which they specifically urge states to realize that Digital Forensics, and by extension Digital Examiners, is a separate field. Moreover, they argue that DEs and other similar technical investigative professions, such as penetration testers, should not be required to obtain a PI license (ABA, 2009). In our previous studies (Lonardo, White, \& Rea, 2008, 2009) we reported that state legislatures appeared to be providing additional attention to this issue due to the controversy surrounding licensing. Since our last review in 2009, there has been some movement in those states who have reported that no license is required and those who report a license is required. Georgia has codified the licensing requirement for Digital Examiners under their PI statue as did Maine (although Maine's statue is somewhat contradictory as discussed in Section 2.4). South Carolina attempted to amend and Virginia amended statutes to exclude Digital Examiners under their respective statues. Illinois issued an opinion letter (dated 7-12-10) stating no PI license is required. 


\subsection{Addressing the Situation}

In our original paper (Lonardo et al., 2008), we examined how each state, as well as Washington DC, interpreted and implemented Digital Examiner licensing. We found that the licensing requirements can create a conflation between $\mathrm{DE}$ activities and PI licensing requirements that may be detrimental to both if not correctly interpreted and implemented. In the requirements we routinely discovered interpretations of language permitting any sort of security task (e.g., Penetration Testing) to be part of the PI realm. As has been mentioned earlier, some states have gone beyond this standard to begin including other areas as well.

Moreover, there are diverse requirements. In some states there are no licensing requirements for Private Investigators; while in others, the profession is governed by statute and or regulatory bodies charged with the oversight and licensing. In some statutes, requirements are implicitly defined; in others the role of DE and PI is either conflated or distinguished. And in other statutes there is no guidance whatsoever. These disparities cause confusion and hinder attempts to identify and license qualified professionals.

It must be granted that Digital Examiner is a relatively new profession, but we have found that many states determine how the profession is regulated. Unfortunately, many states default to their PI licensing boards to do so. This is a matter of procedure since it allows them to combine all professional investigative licensing requirements. We see many repercussions to this decision resulting, such as the lawsuit filed in Texas by computer repair technicians who claim that this prevents them from being able to work since they cannot obtain the license based on the diverging requirements of the two professions (Rife, 2007).

In this paper, we update our original (Lonardo et al., 2008) study that provided the first set of responses from the state boards and discuss changes from our followup paper (Lonardo et al., 2009). We first review statutes for amendments and changes, analyze and interpret existing regulations, then discuss results of our third round of requests from state agencies for statute interpretations. We caution that we do not offer legal advice to practitioners; however, we do offer a starting point from which practitioners can make informed decisions about licensing in their state and take action accordingly. Moreover, we must stress that state legalization and statutes are continually changing because of new legal interpretations and other changes in agency perspectives. Subsequent research will follow as we track the evolution of state licensing statutes. Moreover, we have created a Twitter feed called pilaws (White, Lonardo, \& Rea, 2012) to provide interim updates during the course of the year between paper updates. We encourage interested parties to follow and contribute.

\section{METHODOLOGY 2.1 STUDY APPROACH}

To retain consistency, we use our original definition of a Digital Examiner as a 
means of posing questions to the states:

A Digital Examiner deals with the extracting, gathering and analyzing data from a computer or computers, networks, and other digital media with subsequent preparation of reports and opinions on this media for evidentiary or other stated purposes such as data/digital security, audit, or assessment. (Lonardo et al., 2008)

We also use all of the reviewed state statutes from our 2009 paper (Lonardo et al., 2009) as a starting point for this research. The state statutes were first examined for any legislative updates including those states where there was no apparent licensing requirement for the Private Investigators as noted in Lonardo et al. (2008, 2009). Additionally, the statutes were then scrutinized to determine whether the PI licensing statutes were contained in the typical "business regulation" statutory titles as found in the vast majority of states. Unless the statute clearly exempted the DE from a licensing requirement or there was no apparent PI licensing requirement at all, the appropriate regulatory body was contacted by email, postal mail, or a follow up by phone if the mail-based methods were not successful in obtaining a response. Those groups that had indicated a response to the 2009 paper were asked if there was a change in the position from the preceding year and those who had not responded previously were sent the full inquiry letter found in Figure 1.

Dear

I am researching the requirements of various Private Investigator/Detective licensing requirements relating to Digital/Computer Forensic Examiners. I reviewed the statute; however, I did not see any exclusion in the statute relating to whether a Private Investigator/Detective license is required for Digital/Computer Forensic Examiners. The role and activities of a Digital/Computer Forensic Examiner may include:

- Acquiring data from a computer

- Examining that data and opine on content

- Processing that data to obtain information to answer questions

- Processing that data to prepare it as evidence

In short, the activities of a Digital/Computer Forensic Examiner deals with the extracting, gathering and analyzing data from a computer or computers and preparing reports on the same. For example, if a government agency or private concern hires a digital examiner to 


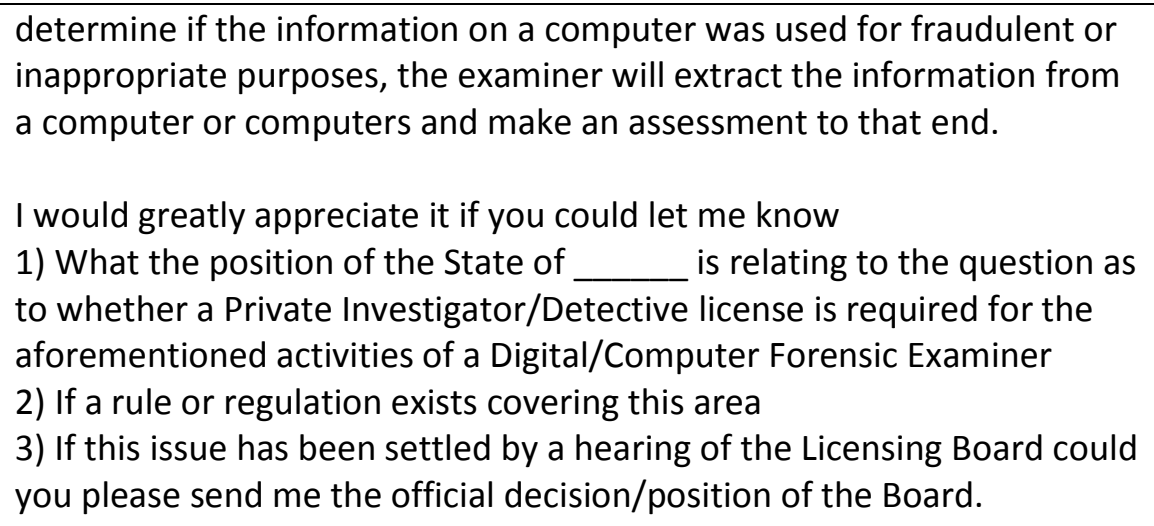
is relating to the question as to whether a Private Investigator/Detective license is required for the aforementioned activities of a Digital/Computer Forensic Examiner 2) If a rule or regulation exists covering this area

3) If this issue has been settled by a hearing of the Licensing Board could you please send me the official decision/position of the Board.

\section{Figure 1}

All requests were sent via email when this was possible which allowed for ease of contact, simplification of analysis, and a record of the provided response. Inquiries were conducted from July 2010 to June 2011 because many legislative sessions conclude in April or May and resume in September or October. Our survey time frame situates itself as best suited to the analysis with regards to likely changes in the state statutes.

It is worth noting that each state manages these regulating bodies in differing ways and thus we use the term "regulatory body" as a means to describe the various entities (e.g. Protective Services Board, Department of Public Safety, etc.).

As per our previous research (Lonardo et al., 2008, 2009), when we advocated an opinion, we based it solely on the language contained in the state's code. For example, if a state used language, such as "to prove the truth or falsity of a statement," or "performing investigations for the court," or similar language, we classified our opinion as "likely required." Other states used strong exclusionary language without being specific, such as "exceptions include engineers and scientists." When we encountered this language that implies scientific investigation, we classified our opinion as "likely not required."

As in the past, all of the opinions are subjective and based on our reading of present state codes and the continuation of those opinions from the 2008 and 2009 papers. As our study demonstrates, state regulatory bodies have varying opinions; language is subject to varying interpretations and in cases where we did not receive responses from state officials, our opinion should be taken in the same context.

\subsection{Examination of Language Used}

Lonardo et al. $(2008,2009)$ provides a review of the language that is typical of the 
various states. Still we pose some brief samples here to illustrate the challenges faced when determining a particular state statute application to the licensing question. Figure 2 provides an illustration from Arizona:

The Arizona Statute Title 32 \$2410 defines a Private Investigator:

"Private investigator" means a person other than an insurance adjuster or
an on-duty peace officer as defined in section 1-215 who, for any
consideration, engages in business or accepts employment to:
(a) Furnish, agree to make or make any investigation for the
purpose of obtaining information with reference to:
(i) Crime or wrongs done or threatened against the United
States or any state or territory of the United States.
(ii) The identity, habits, conduct, movements,
whereabouts, affiliations, associations, transactions,
reputation or character of any person or group of persons.
(iii) The credibility of witnesses or other persons.
(iv) The whereabouts of missing persons, owners of
abandoned property or escheated property or heirs to
estates.
(v) The location or recovery of lost or stolen property.
(vi) The causes and origin of, or responsibility for, a fire,
libel, slander, a loss, an accident, damage or an injury to
real or personal property.

(b) Secure evidence to be used before investigating committees or boards of award or arbitration or in the trial of civil or criminal cases and the preparation therefor.

(c) Investigate threats of violence and provide the service of protection of individuals from serious bodily harm or death.

Figure 2: Arizona Statute Title $32 \S 2410$

A similar set of language is found in Texas as is seen in Figure 3: 


\section{Sec. 1702.104. INVESTIGATIONS COMPANY.}

(a) A person acts as an investigations company for the purposes of this chapter if the person:

(1) engages in the business of obtaining or furnishing, or accepts employment to obtain or furnish, information related to:

(A) crime or wrongs done or threatened against a state or the United States;

(B) the identity, habits, business, occupation, knowledge, efficiency, loyalty, movement, location, affiliations, associations, transactions, acts, reputation, or character of a person;

(C) the location, disposition, or recovery of lost or stolen property; or

(D) the cause or responsibility for a fire, libel, loss, accident, damage, or injury to a person or to property;

Figure 3: Texas Occupations Code Title $10 \S 1702.104$ (a) excerpt

As noted earlier in our discussion, Texas has extended this code to include specifics regarding Computer Technology as seen in Figure 4. This has caused some contention from computer-based business owners and technicians.

(b) For purposes of Subsection (a)(1), obtaining or furnishing information includes information obtained or furnished through the review and analysis of, and the investigation into the content of, computer-based data not available to the public.

Figure 4: Texas Occupations Code Title $10 \S$ 1702.104(b)

The Connecticut statute under Chapter 534 Sec. 29-152u (4) defines a PI in almost the same terms as the Arizona statute:

\footnotetext{
"Private detective" means any person engaged in the business of, or advertising as engaged in the business of $(A)$ investigating crimes or civil wrongs, (B) investigating the location, disposition or recovery of property, (C) investigating the cause of accidents, fire damage or injuries to persons or to property, except persons performing bona fide engineering services, (D) providing the personal protection of individuals, $(E)$ conducting surveillance activity, (F) conducting background investigations, or (G) securing evidence to be used before a court, board, officer or investigation committee;
}

Figure 5: Connecticut statute under Chapter 534 Sec. 29-152u (4) 
However, under Connecticut's statutory language, the regulator we contacted noted that a PI license--and by extension a Digital Examiner--is not required. We have found that this open-ended interpretation has resulted in many states interpreting the Digital Examiner role and profession disparately and inconsistently.

Vague language and diverse interpretation is still the norm, such as with the language used to determine licensing requirements in Nebraska's statute (Neb. Rev. Stat. § 71-3201):

(6) Private detective shall mean any individual who as a sole proprietor engages in the private detective business without the assistance of any employee;

(8) Private detective business shall mean and include any private business engaged in by any person defined in subdivision (4) of this section who advertises or holds himself or herself out to the public, in any manner, as being engaged in the secret service or private policing business;

Figure 6: Nebraska Rev. Stat. § 71-3201

Under Nebraska's statute a private detective is one who is "engaged in the secret service or private policing business." However, neither the functionality of Arizona's nor Connecticut's statutes is incorporated into the language of the Nebraska statute. Thus, in Nebraska's opinion, a license is not required.

However, we did find that Nebraska's Chapter $1 \S 002$ of the "Rules \& Regulations for Private Detective, Plain Clothes Investigators and Private Detective Agencies" does explain the profession's functionality in greater detail even though it is not as specific as others we examined:

002. Secret service or private policing business shall mean and include: general investigative work; non-uniformed security services; surveillance services; location of missing persons; and background checks.

Figure 7: Nebraska Chapter $1 \S 002$

\subsection{Exemptions in the Language}

We must point out that a number of the state statutes did not need interpretation because they listed exemptions to the PI licensing requirement. Most, if not all, of 
these exemptions would exclude a Digital Examiner from PI licensing requirements, but perhaps not from other professional licensing requirements (e.g., State Bar Exam) or certification (e.g., CPA). However 21 of the states that reflect either a license is, or is not required, is based on the appropriate regulatory body's opinion and thus the PI statute is silent on whether it applies to Digital Examiners. The exemptions typically included:

- Persons under the regular employment of an employer where there is a bona fide employer-employee relationship;

- An officer or employee of the United States, the state where the public employee is employed, or a political subdivision of the state;

- The business of obtaining and furnishing information as to the financial standing, rating, and credit responsibility of persons or as to the personal habits and financial responsibility of applicants for insurance, indemnity bonds, or commercial credit;

- A charitable philanthropic society or association;

- An attorney admitted to practice in the state in performing his or her duties as an attorney at law;

- A collection agency or finance company licensed to do business under the laws of this state or any employee of a collection agency or finance company while performing within the scope of their duties;

- Claims adjusters of insurance companies;

- A professional engineer acting within the scope of his or her licensed professional practice who does not perform investigative services;

- A certified public accountant acting within the scope of his or her licensed professional practice who does not perform investigative services;

- Bail agents.

The state of Virginia went further in 2011 by codifying the exemption language to be more explicit and certain. Prior statutory review reflected an exemption from the PI licensing requirement through interpretation of the then existing exemption language that stated that the provisions of the article did not apply to:

17. Any certified forensic scientist employed as an expert witness for the purpose of possibly testifying as an expert witness" (emphasis added)

The code was amended retaining the above exemption but also adding:

29. Any individual engaged in (i) computer or digital forensic services as defined in § 9.1-138 or in the acquisition, review, or analysis of digital or computer-based information, in order to obtain or furnish 


\section{information for evidentiary purposes or to provide expert testimony before a court, or (ii) network or system vulnerability testing, including network scans and risk assessment and analysis of computers connected to a network.}

In a similar fashion to the requirements, the exemptions follow no particular pattern but do in some cases exclude practitioners either directly or indirectly. Moreover, we are seeing a new trend in what we have termed "limited exclusions."

\subsection{Limited Exclusions}

Cases where we have identified "Limited Exclusions" involve those regulatory opinions that add some guidance but needs further clarification. For example, New Hampshire has rendered an opinion that a license is not required "as long as it is strictly the examination of evidence."

This opinion leaves the reader to wonder what exactly "examination of evidence" means in the context of a digital examiner's function. Would this include retrieving the information from the computer or storage device (i.e., external hard drive or thumb drive) in order to examine evidence? We are currently awaiting a response to this inquiry.

Another example of a "limited Exclusion" is seen in the 2009 board meeting minutes for the Nevada Private Investigators Licensing Board that exempts licensing if the DE engages solely in "data retrieval." However, the question then becomes how is this reconciled with the language of the statute? Would a DE be permitted to retrieve data but not secure it without running afoul of the statute, NRS 648.012 (4):

...any person who for any consideration engages in business or accepts employment to furnish, or agrees to make or makes any investigation for the purpose of obtaining, information with reference to:

Securing evidence to be used before any court, board, officer or investigating committee;

Finally, Maine has somewhat clouded the waters. Previously, Maine did not require licensing, but in 2011 has conflated the role of Private Investigator and Digital Examiner with statue 8103(4)(A) that now requires PI licensing for any collected evidence, "including evidence derived through computer forensics" (emphasis added). However, Maine's statue does provide an exception in 8104(2)(L) for 
A person acting within the scope of the person's professional practice to analyze facts, evidence or other data for the purposes of supplying expert testimony in a legal proceeding; [2011, c. 366, §26 (NEW).] (emphasis added)

In other words, one needs to be licensed to collect evidence, but not to analyze it and present it. This is a troubling distinction. For now, we are classifying this as "license required."

\section{DISCUSSION OF FINDINGS 3.1 INITIAL REVIEW}

As noted above, we began our review by reexamining the state statutes from the previous year. We list all the statues in Table 1.

Table 1: State Statutes

\begin{tabular}{|ll|}
\hline \multicolumn{1}{|c|}{ State } & Statute \\
\hline Alabama & No Requirement \\
\hline Alaska & No Requirement \\
\hline Arizona & Chap. 24 - 32-2401 \\
\hline Arkansas & $17-40$ \\
\hline California & 7520 State Law \\
\hline Colorado & $12-58.5-104$ \\
\hline Connecticut & Chap. 534 Sec 29 \\
\hline Delaware & $24-1301$ \\
\hline District of Columbia & Division VIII Title 47 \\
\hline Florida & Title 32 Chap. 493 \\
\hline Georgia & Title 43 - Chap. 38 \\
\hline Hawaii & HRS Chap. 463 \\
\hline Idaho & No Requirement \\
\hline & \\
\hline
\end{tabular}


Journal of Digital Forensics, Security and Law, Vol. 7(3)

\begin{tabular}{|c|c|}
\hline Illinois & 225 ILCS 447 Art 5-10.1.2 \\
\hline Indiana & IC 25-30 \\
\hline lowa & IC Chap. 80A \\
\hline Kansas & Chap. 75 - 7b \\
\hline Kentucky & KRS 329A \\
\hline Louisiana & LA RS:37 3500 \\
\hline Maine & $8103(4)(A), 8104(2)(L)$ \\
\hline Maryland & Title 13-101 \\
\hline Massachusetts & Title XX 147 s22 \\
\hline Michigan & Chap. 338.822 \\
\hline Minnesota & 326.338 \\
\hline Mississippi & NA \\
\hline Missouri & NA \\
\hline Montana & $37-60-105$ \\
\hline Nebraska & $72-3201$ \\
\hline Nevada & 648.012 \\
\hline New Hampshire & $106-F$ \\
\hline New Jersey & $45: 19-9$ \\
\hline New Mexico & 61 Article 27B \\
\hline New York & Article $7 \mathrm{Sec} 71$ \\
\hline North Carolina & $74 c-3(b)$ \\
\hline North Dakota & $43-30$ \\
\hline
\end{tabular}


Journal of Digital Forensics, Security and Law, Vol. 7(3)

\begin{tabular}{|c|c|}
\hline Ohio & 4749.01 \\
\hline Oklahoma & Title 59 - 42a-1750 \\
\hline Oregon & $703.401,405,407,411$ \\
\hline Pennsylvania & Unknown \\
\hline Rhode Island & Chap. 5-5 \\
\hline South Carolina & Title 40 Chap. 18 \\
\hline South Dakota & No Requirement \\
\hline Tennessee & Title 62 Chap. 26223 \\
\hline Texas & 1702.104 \\
\hline Utah & $53-9-102$ \\
\hline Vermont & Title 26 Chap. 59 \\
\hline Virginia & $9-1-138 ; 9-1-140$ \\
\hline Washington & 18.165 .10 \\
\hline West Virginia & $30-18$ \\
\hline Wisconsin & 440.26 \\
\hline Wyoming & No Requirement \\
\hline
\end{tabular}

\subsection{Summary of Responses}

After we reviewed the statutes, we began a new round of inquiries to the states as per our methodology. The response categories ranged from "No License Required," "License Required," "Under Review," "No Response," "No Opinion" and "License required with limiting circumstances."

For example, the District of Columbia requires a physical presence in DC in order to require a license. However, if the computer or data is originally obtained in DC, but the examination of the evidence is conducted in a state not requiring a license, a DC license is not required. 
In Nevada, the board opined that "The Board did not license data recovery, but what was done with that information would require an investigators license." This would then exclude imaging but would cover examination. Wisconsin and California have taken a similar position to Nevada. We expect states to make more distinctions such as these are they begin to understand the differences between PI and DE.

Colorado recently (July 2012) distinguished between "licensed private investigator" and "private investigator" with the former requiring a license. When we examined this distinction within the context of our paper we determined the only thing this does is allow a title of "Licensed Private Investigator" under a voluntary program with certain requirements and a $\$ 320$ fee. It doesn't affect Digital Examiners/Computer Forensic professionals. However, this may be one step towards mandatory licensing in the future. The statute has a sunset clause and expires in 2016, so this is definitely one we must monitor because this may lead to more confusion than clarity.

Voluntary license-title protection-penalty 12-58.5-104. 1(b)

b) Nothing in this article requires a private investigator engaging in private investigations in this state to obtain a license under this article, but a private investigator who is not so licensed shall not refer to himself or herself as a "licensed private investigator".

In South Carolina, a proposed statute change would have permitted a licensing exception for DEs and thereby added another state that recognized the necessary distinction between roles. However, on June 18, 2012, the governor vetoed the exception. South Carolina remains a state that requires the licensing of DEs.

Unfortunately, one major change between 2009 and this current study is reflected in the response rate. In 2009, we received "no response" from only three (3) states. This study however reflects six (6) states that failed to generate a follow-up response of some kind. However, five (5) of the "no responses" were from states previously rendering an opinion of "No License Required," whereas one (1) has never responded to any survey requests.

Table 2 provides linkages to the state statutes with the Title and Part of the statute that directly refers to this study.

Table 2: State Statutes and Links

\begin{tabular}{|ll|}
\hline \multicolumn{1}{|c|}{ State } & \multicolumn{1}{c|}{ Belief } \\
\hline Alabama & $\begin{array}{l}\text { No PI Licensing } \\
\text { Requirement }\end{array}$ \\
\hline Alaska & No PI Licensing \\
\hline
\end{tabular}


Journal of Digital Forensics, Security and Law, Vol. 7(3)

\begin{tabular}{|c|c|c|c|}
\hline & Requirement & & \\
\hline Arizona & $\begin{array}{l}\text { Not specific but } \\
\text { statements }\end{array}$ & $\begin{array}{l}\text { Chap. } 24 \\
-32- \\
2401\end{array}$ & $\begin{array}{l}\text { http://www.azleg.state.az.us/FormatDocume } \\
\text { nt.asp?inDoc=/ars/32/02401.htm\&Title=32\&D } \\
\text { ocType=ARS }\end{array}$ \\
\hline Arkansas & $\begin{array}{l}\text { Not Specific but } \\
\text { statements }\end{array}$ & $17-40$ & $\begin{array}{l}\text { http://www.arkleg.state.ar.us/bureau/Publica } \\
\text { tions/Arkansas\%20Code/Title\%2017.pdf }\end{array}$ \\
\hline California & $\begin{array}{l}\text { Not Specific but } \\
\text { statements }\end{array}$ & $\begin{array}{l}7520 \\
\text { State } \\
\text { Law }\end{array}$ & $\begin{array}{l}\text { http://www.leginfo.ca.gov/cgi- } \\
\text { bin/displaycode?section=bpc\&group=07001- } \\
\underline{08000 \& \text { file }=7520-7539}\end{array}$ \\
\hline Colorado & $\begin{array}{l}\text { Voluntary PI if } \\
\text { use "licensed" } \\
\text { in title }\end{array}$ & $\begin{array}{l}12-58.5- \\
104.1(b)\end{array}$ & $\begin{array}{l}\text { http://www.michie.com/colorado/lpext.dll/co } \\
\text { code/1/17f02/1ab8a/1d2ed/1ed47/1ed7a?f=t } \\
\text { emplates\&fn=document- } \\
\text { frame.htm\&q=private\%20investigator\&x=Adv } \\
\text { anced\&2.0\#LPHit1 }\end{array}$ \\
\hline Connecticut & $\begin{array}{l}\text { Not Specific but } \\
\text { statements }\end{array}$ & $\begin{array}{l}\text { Chap. } \\
534 \text { Sec. } \\
29\end{array}$ & $\begin{array}{l}\text { http://www.cga.ct.gov/2005/pub/Chap534.ht } \\
\text { m\#Sec29-153.htm }\end{array}$ \\
\hline Delaware & $\begin{array}{l}\text { PI but excludes } \\
\text { CCE }\end{array}$ & $\begin{array}{l}24- \\
1301\end{array}$ & $\begin{array}{l}\text { http://delcode.delaware.gov/title24/c013/ind } \\
\text { ex.shtml }\end{array}$ \\
\hline $\begin{array}{l}\text { District of } \\
\text { Columbia }\end{array}$ & $\begin{array}{l}\text { Seems to } \\
\text { require but } \\
\text { unknown }\end{array}$ & $\begin{array}{l}\text { Division } \\
\text { VIII Title } \\
47\end{array}$ & \\
\hline Florida & $\begin{array}{l}\text { Not Specific but } \\
\text { statements }\end{array}$ & $\begin{array}{l}\text { Title } 32 \\
\text { Chap. } \\
493\end{array}$ & $\begin{array}{l}\text { http://www.flsenate.gov/Statutes/index.cfm? } \\
\text { App mode=Display Statute\&URL=Ch0493/titl } \\
\underline{0493 . h t m}\end{array}$ \\
\hline Georgia & $\begin{array}{l}\text { Not Specific but } \\
\text { statements }\end{array}$ & $\begin{array}{l}\text { Title } 43 \\
\text { - Chap. } \\
38\end{array}$ & $\begin{array}{l}\text { http://www.lexis- } \\
\text { nexis.com/hottopics/gacode/Default.asp }\end{array}$ \\
\hline Hawaii & $\begin{array}{l}\text { May imply as it } \\
\text { states all } \\
\text { investigation }\end{array}$ & $\begin{array}{l}\text { HRS } \\
\text { Chap. } \\
463\end{array}$ & $\begin{array}{l}\text { http://hawaii.gov/dcca/pvl/hrs/hrs pvl 463.p } \\
\text { df/view }\end{array}$ \\
\hline
\end{tabular}


Journal of Digital Forensics, Security and Law, Vol. 7(3)

\begin{tabular}{|c|c|c|c|}
\hline Idaho & $\begin{array}{l}\text { No PI Licensing } \\
\text { Requirement }\end{array}$ & & \\
\hline Illinois & $\begin{array}{l}\text { Includes } \\
\text { "electronics" in } \\
\text { the definition of } \\
\text { investigation. }\end{array}$ & $\begin{array}{l}225 \text { ILCS } \\
447 \text { Art } \\
5-10.1 .2\end{array}$ & $\begin{array}{l}\text { http://ilga.gov/legislation/ilcs/ilcs5.asp?ActID } \\
=2474 \& \text { ChapAct=225\%AOILCS\%A0447\%2F\&Ch } \\
\text { apterID=24\&ChapterName=PROFESSIONS+AN } \\
\text { D+OCCUPATIONS\&ActName=Private+Detectiv } \\
\text { e\%2C+Private+Alarm\%2C+Private+Security\%2 } \\
\text { C+and+Locksmith+Act+of+2004\%2E }\end{array}$ \\
\hline Indiana & $\begin{array}{l}\text { Not Specific but } \\
\text { statements }\end{array}$ & IC $25-30$ & $\begin{array}{l}\text { http://www.in.gov/legislative/ic/code/title25/ } \\
\text { ar30/ch1.html }\end{array}$ \\
\hline lowa & $\begin{array}{l}\text { Not Specific but } \\
\text { statements }\end{array}$ & $\begin{array}{l}\text { IC Chap. } \\
80 \mathrm{~A}\end{array}$ & $\begin{array}{l}\text { http://www.dps.state.ia.us/asd/pi/pi80a03co } \\
\text { de.pdf }\end{array}$ \\
\hline Kansas & $\begin{array}{l}\text { Not Specific but } \\
\text { statements }\end{array}$ & $\begin{array}{l}\text { Chap. } 75 \\
-7 \mathrm{~b}\end{array}$ & $\begin{array}{l}\text { http://www.kslegislature.org/legsrv- } \\
\text { statutes/index.do }\end{array}$ \\
\hline Kentucky & $\begin{array}{l}\text { Not Specific but } \\
\text { statements }\end{array}$ & $\begin{array}{l}\text { KRS } \\
329 A\end{array}$ & $\begin{array}{l}\text { http://www.lrc.state.ky.us/KRS/329A00/CHAP } \\
\text { TER.HTM }\end{array}$ \\
\hline Louisiana & $\begin{array}{l}\text { Excludes } \\
\text { technical } \\
\text { experts }\end{array}$ & $\begin{array}{l}\text { LA RS:37 } \\
3500\end{array}$ & http://www.Isbpie.com/pilaw 4 02.pdf \\
\hline Maine & $\begin{array}{l}\text { Not Specific but } \\
\text { statements }\end{array}$ & $\begin{array}{l}8103(4)( \\
\text { A), } \\
8104(2)( \\
\text { L) }\end{array}$ & $\begin{array}{l}\text { http://www.mainelegislature.org/legis/st } \\
\text { atutes/32/title32sec8103-A.html } \\
\text { http://www.mainelegislature.org/legis/st } \\
\text { atutes/32/title32sec8104.html }\end{array}$ \\
\hline Maryland & $\begin{array}{l}\text { Not Specific but } \\
\text { statements }\end{array}$ & $\begin{array}{l}\text { Title 13- } \\
101\end{array}$ & $\begin{array}{l}\text { http://michie.lexisnexis.com/maryland/lpext. } \\
\text { dll/mdcode/1564/227a?fn=document- } \\
\text { frame.htm\&f=templates\&2.0\# }\end{array}$ \\
\hline $\begin{array}{l}\text { Massachusett } \\
s\end{array}$ & $\begin{array}{l}\text { Not Specific but } \\
\text { statements }\end{array}$ & $\begin{array}{l}\text { Title XX } \\
147 \text { s22 }\end{array}$ & $\begin{array}{l}\text { http://www.mass.gov/legis/laws/mgl/gl-147- } \\
\text { toc.htm }\end{array}$ \\
\hline Michigan & $\begin{array}{l}\text { Not Specific but } \\
\text { statements }\end{array}$ & $\begin{array}{l}\text { Chap. } \\
338.822\end{array}$ & $\begin{array}{l}\text { http://www.legislature.mi.gov/(S(543gin45g1 } \\
\text { xwihrunhpsds45))/mileg.aspx?page=getObject }\end{array}$ \\
\hline
\end{tabular}


Journal of Digital Forensics, Security and Law, Vol. 7(3)

\begin{tabular}{|c|c|c|c|}
\hline & & & \&objectName=mcl-Act-285-of-1965 \\
\hline Minnesota & $\begin{array}{l}\text { Not Specific but } \\
\text { statements }\end{array}$ & 326.338 & $\begin{array}{l}\text { http://www.dps.state.mn.us/pdb/Resources/ } \\
\text { PDPA Minnesota Statutes.pdf }\end{array}$ \\
\hline Mississippi & \multicolumn{3}{|c|}{ Not Specific but statements } \\
\hline Missouri & \multicolumn{2}{|l|}{$\begin{array}{l}\text { Not } \\
\text { Specific } \\
\text { but } \\
\text { stateme } \\
\text { nts }\end{array}$} & $\begin{array}{l}\text { רttp://www.moga.mo.gov/statutes/chapters/c } \\
\text { רap324.htm }\end{array}$ \\
\hline Montana & $\begin{array}{l}\text { Not Specific but } \\
\text { statements }\end{array}$ & $37-60$ & $\begin{array}{l}\text { http://data.opi.state.mt.us/bills/mca toc/37 } \\
60 \text { 1.htm }\end{array}$ \\
\hline Nebraska & $\begin{array}{l}\text { Should not } \\
\text { apply unless } \\
\text { you advertise as } \\
\text { private } \\
\text { detective }\end{array}$ & $72-3201$ & $\begin{array}{l}\text { http://www.sos.state.ne.us/rules-and- } \\
\text { regs/regsearch/Rules/Secretary of State/Titl } \\
\text { e-435.pdf }\end{array}$ \\
\hline Nevada & $\begin{array}{l}\text { Not Specific but } \\
\text { statements }\end{array}$ & 648.012 & $\begin{array}{l}\text { http://www.leg.state.nv.us/NRS/NRS- } \\
\text { 648.html\#NRS648Sec006 }\end{array}$ \\
\hline $\begin{array}{l}\text { New } \\
\text { Hampshire }\end{array}$ & $\begin{array}{l}\text { Not Specific but } \\
\text { crime } \\
\text { statement }\end{array}$ & $106-\mathrm{F}$ & $\begin{array}{l}\text { http://www.gencourt.state.nh.us/rsa/html/vii } \\
106-f / 106-f-m r g . h t m\end{array}$ \\
\hline New Jersey & $\begin{array}{l}\text { Not Specific but } \\
\text { statements }\end{array}$ & $45: 19-9$ & $\begin{array}{l}\text { http://www.state.nj.us/njsp/about/pdf/06010 } \\
6 \text { amendedstat.pdf }\end{array}$ \\
\hline New Mexico & $\begin{array}{l}\text { Not Specific but } \\
\text { statements }\end{array}$ & $\begin{array}{l}61 \\
\text { Article } \\
27 \mathrm{~B}\end{array}$ & $\begin{array}{l}\text { http://www.conwaygreene.com/nmsu/lpext. } \\
\text { dll/nmsa1978/9b0/1d78b/1ef8f/1f105?f=tem } \\
\text { plates\&fn=document-frame.htm\&2.0 }\end{array}$ \\
\hline New York & $\begin{array}{l}\text { Not Specific but } \\
\text { statements }\end{array}$ & $\begin{array}{l}\text { Article } 7 \\
\text { Sec } 71\end{array}$ & $\begin{array}{l}\text { http://www.dos.state.ny.us/lcns/lawbooks/pi } \\
\text { beawgpa.html }\end{array}$ \\
\hline $\begin{array}{l}\text { North } \\
\text { Carolina }\end{array}$ & $\begin{array}{l}\text { Excluded } \\
\text { Indirectly }\end{array}$ & $74 C-3$ & $\begin{array}{l}\text { http://www.ncleg.net/EnactedLegislation/Stat } \\
\text { utes/HTML/ByChapter/Chapter 74C.html }\end{array}$ \\
\hline
\end{tabular}


Journal of Digital Forensics, Security and Law, Vol. 7(3)

\begin{tabular}{|c|c|c|c|}
\hline North Dakota & Excluded & $43-30$ & http://www.legis.nd.gov/cencode/t43c30.pdf \\
\hline Ohio & $\begin{array}{l}\text { Not Specific but } \\
\text { statements }\end{array}$ & 4749.01 & http://codes.ohio.gov/orc/4749 \\
\hline Oklahoma & $\begin{array}{l}\text { Not Specific but } \\
\text { statements }\end{array}$ & $\begin{array}{l}\text { Title } 59- \\
42 a- \\
1750\end{array}$ & $\begin{array}{l}\text { http://www.oscn.net/applications/oscn/Deliv } \\
\text { erDocument.asp?CitelD=96644 }\end{array}$ \\
\hline Oregon & $\begin{array}{l}\text { Not Specific but } \\
\text { statements }\end{array}$ & 703.4 & http://www.leg.state.or.us/ors/703.html \\
\hline Pennsylvania & \multicolumn{3}{|c|}{ License is required in some counties. } \\
\hline Rhode Island & $\begin{array}{l}\text { Not Specific but } \\
\text { statements }\end{array}$ & $\begin{array}{l}\text { Chap. 5- } \\
5\end{array}$ & $\begin{array}{l}\text { http://www.rilin.state.ri.us/Statutes/Title5/5- } \\
\text { 5/INDEX.HTM }\end{array}$ \\
\hline $\begin{array}{l}\text { South } \\
\text { Carolina }\end{array}$ & $\begin{array}{l}\text { Not Specific but } \\
\text { statements }\end{array}$ & $\begin{array}{l}\text { Title } 40 \\
\text { Chap. } 18\end{array}$ & $\begin{array}{l}\text { http://www.scstatehouse.net/code/t40c018.h } \\
\underline{t m}\end{array}$ \\
\hline South Dakota & $\begin{array}{l}\text { No PI Licensing } \\
\text { Requirement }\end{array}$ & & \\
\hline Tennessee & $\begin{array}{l}\text { Not Specific but } \\
\text { statements }\end{array}$ & $\begin{array}{l}\text { Title } 62 \\
\text { Chap. } 26 \\
223\end{array}$ & $\begin{array}{l}\text { http://michie.lexisnexis.com/tennessee/lpe } \\
\text { xt.dll/tncode/24296/24fbc/24fc3/25044?f= } \\
\text { templates\&fn=document- } \\
\text { frame.htm\&2.0\#JD_62-26-223 }\end{array}$ \\
\hline Texas & $\begin{array}{l}\text { Specifically } \\
\text { includes CF }\end{array}$ & $\begin{array}{l}1702.10 \\
4\end{array}$ & $\begin{array}{l}\text { http://www.statutes.legis.state.tx.us/Docs/O } \\
\text { c/htm/OC.1702.htm }\end{array}$ \\
\hline Utah & $\begin{array}{l}\text { Not Specific but } \\
\text { statements }\end{array}$ & 53-9-102 & $\begin{array}{l}\text { http://le.utah.gov/UtahCode/getCodeSection } \\
\text { ?code=53-9-102 }\end{array}$ \\
\hline Vermont & $\begin{array}{l}\text { Not Specific but } \\
\text { statements }\end{array}$ & $\begin{array}{l}\text { Title } 26 \\
\text { Chap. } 59\end{array}$ & $\begin{array}{l}\text { http://www.leg.state.vt.us/statutes/fullchapt } \\
\text { er.cfm?Title=26\&Chapter=059 }\end{array}$ \\
\hline Virginia & $\begin{array}{l}\text { Specifically } \\
\text { excludes } \\
\text { forensics } \\
\text { examiners }\end{array}$ & $9-1-138$ & $\begin{array}{l}\text { http://leg1.state.va.us/cgi- } \\
\text { bin/legp504.exe?000+cod+9.1-138 }\end{array}$ \\
\hline
\end{tabular}




\begin{tabular}{|c|c|c|c|}
\hline Washington & $\begin{array}{l}\text { Specifically } \\
\text { excludes } \\
\text { forensics } \\
\text { examiners }\end{array}$ & $\begin{array}{l}18.165 .1 \\
0\end{array}$ & $\begin{array}{l}\text { http://apps.leg.wa.gov/RCW/default.aspx?cit } \\
\text { e=18.165.010 }\end{array}$ \\
\hline West Virginia & $\begin{array}{l}\text { Not Specific but } \\
\text { strong language }\end{array}$ & $30-18$ & $\begin{array}{l}\text { http://www.legis.state.wv.us/WVCODE/Code. } \\
\text { cfm?chap=30\&art=18 }\end{array}$ \\
\hline Wisconsin & $\begin{array}{l}\text { No Specific } \\
\text { language at all } \\
\text { but focused on } \\
\text { advertising as } \\
\text { private } \\
\text { detective }\end{array}$ & 440.26 & $\begin{array}{l}\text { http://www.legis.state.wi.us/statutes/Stat044 } \\
\underline{\text { 0.pdf }}\end{array}$ \\
\hline Wyoming & $\begin{array}{l}\text { No PI Licensing } \\
\text { Req. }\end{array}$ & & \\
\hline
\end{tabular}

\subsection{Explanation of Data}

During the time frame of July 2010 to June 2011, we solicited responses from the various states using our established methods. The data is presented in tables based upon several factors. In some cases, the state has a statute that requires the license or does not require the license. In other cases, the opinion of the governing regulatory body was used based on their response to our inquiry. In all cases, we have attempted to provide an informational resource for practitioners but again must caution that both opinion and statute are dynamic and can change rapidly. Thus, as ever, the practitioner should use caution and contact a licensed attorney or the state licensing board before conducting forensics examinations in any given locale.

The data is presented as follows:

- States that require a PI license and specifically address DEs by statute. (Table 3)

- States that require a PI license, but do not specifically address DEs. There is an opinion issued that includes DEs. (Table 4)

- States that require a PI license, but do not specifically include DEs. There is a present opinion issued that excludes DEs. (Table 5)

- States that require a PI license and specifically exclude DEs by statute. (Table 6)

- States that do not require a PI license by statute. (Table 7) 
Journal of Digital Forensics, Security and Law, Vol. 7(3)

- States that require a PI license but have limited exclusions for DE (Table 8)

- States that did not respond to our inquiry (Table 9)

- States that issues a response of no opinion (Table 10)

Table 3: States that require a PI License and specifically include DEs by statute

\begin{tabular}{|lll|}
\hline State & Requires PI for DE & Statute \\
\hline ME & Yes & $\begin{array}{l}8103(4)(\mathrm{A}), \\
8104(2)(\mathrm{L})\end{array}$ \\
\hline MI & Yes & Chap. 338.822 \\
\hline OR & Yes & $703.401,405,407,411$ \\
\hline TX & Yes & TC 1702.104 \\
\hline
\end{tabular}


Table 4: States that require a PI license, but do not specifically address DEs. There is an opinion issued that includes DEs.

\begin{tabular}{|ll|}
\hline State & Opinion \\
\hline AR & License Required \\
\hline AZ & License Required \\
\hline DC & Licensed Required ${ }^{*}$ \\
\hline GA & License Required ${ }^{*}$ \\
\hline HI & License Required \\
\hline IA & License Required \\
\hline LA & License Required \\
\hline MD & License Required ${ }^{*}$ \\
\hline MO & License Required \\
\hline NM & License Required \\
\hline NV & License Required \\
\hline NY & License Required ${ }^{*}$ \\
\hline SC & License Required \\
\hline WI & License Required \\
\hline WV & License Required \\
\hline
\end{tabular}

${ }^{*}$ Indicates a state that indicated some limited exclusions (see Table 8). 
Table 5: States that require a PI license, but do not specifically include DEs.

There is a present opinion issued that excludes DEs.

\begin{tabular}{|ll|}
\hline State & Opinion \\
\hline CO & $\begin{array}{l}12-58.5-104 \text { (Required if use the } \\
\text { term "licensed") }\end{array}$ \\
\hline CT & No License Required \\
\hline KS & No License Required \\
\hline UT & No License Required \\
\hline
\end{tabular}

Table 6: States that require a PI license and specifically exclude DEs by statute.

\begin{tabular}{|ll|}
\hline State & Statute \\
\hline DE & DSC 24-1301 \\
\hline MT & $37-60-105$ \\
\hline NC & 74C-3(b) \\
\hline ND & NDSC 43-30 \\
\hline NE & Rev. Stat. 72-3201 \\
\hline RI & RSC Chap 5-5 \\
\hline VA & VSC 9-1-138; 9-1-140 \\
\hline WA & WSC 18.165.10 \\
\hline
\end{tabular}


Table 7: States that do not require a PI license at all.

\begin{tabular}{|ll|}
\hline State & Requirement \\
\hline AL & None \\
\hline AK & None \\
ID & None \\
\hline IL & None \\
\hline MS & None \\
\hline PA & May be required by county \\
\hline SD & None \\
\hline WY & None \\
\hline
\end{tabular}

Table 8: States indicating a limited exclusion but otherwise requiring a license

\begin{tabular}{|ll|}
\hline State & Exclusion \\
\hline CA & $\begin{array}{l}\text { Via Phone Interview, written or } \\
\text { verbal inquiries would require PI but } \\
\text { working only on a computer would } \\
\text { not. (continued opinion) }\end{array}$ \\
\hline DC & $\begin{array}{l}\text { Work not being physically done in } \\
\text { DC would not require a license. }\end{array}$ \\
\hline LA & $\begin{array}{l}37: 3500.8(a)(\text { iv) excludes technical } \\
\text { experts }\end{array}$ \\
\hline NV & Licensing board minutes indicate \\
& retrieval is not licensed but analysis \\
& requires license \\
&
\end{tabular}


Unfortunately, in the latest round of queries six (6) states-up from three (3) the previous year-- did not reply to email, mail, or telephone contact attempts. When applicable, we have noted each state's response from our 2009 survey; however, we have removed these states from other tables as their exact status could not be determined. We will add additional inquiry opportunities for these states in the upcoming survey. The six (6) nonresponding states and our opinion are listed below in Table 9.

Table 9: States with Unknown Status

\begin{tabular}{|lll|}
\hline State & Status & Our Opinion \\
\hline FL & Previous Response & $\begin{array}{l}\text { No License } \\
\text { Requirement. Opinion } \\
\text { excludes DEs. }\end{array}$ \\
\hline MA & No Response & $\begin{array}{l}\text { Hearsay indicates } \\
\text { required }\end{array}$ \\
\hline NH & Previous Response & $\begin{array}{l}\text { No License } \\
\text { Requirement. Opinion } \\
\text { includes DEs. }\end{array}$ \\
\hline OH & Previous Response & $\begin{array}{l}\text { No License } \\
\text { Requirement. Opinion } \\
\text { excludes DEs. }\end{array}$ \\
& & $\begin{array}{l}\text { No License } \\
\text { Requirement. Opinion } \\
\text { excludes DEs. }\end{array}$ \\
\hline OK & Previous Response & $\begin{array}{l}\text { No License } \\
\text { Requirement. Opinion } \\
\text { excludes DEs. }\end{array}$ \\
& & \\
\hline VT & Previous Response & \\
& &
\end{tabular}


Of states that did respond, five (5) declined to render an opinion on DE licensing requirements (Table 10):

Table 10: States that issued a response of No Opinion

\begin{tabular}{|lll|}
\hline State & Response & Our Opinion \\
\hline IN & No Opinion & Only if you advertise as a PI \\
\hline KY & No Opinion & $\begin{array}{l}\text { Implies any sort of investigation } \\
\text { requires a license. }\end{array}$ \\
\hline MN & No Opinion & May be required \\
\hline NJ & Indicated it was & Waiting for review \\
& under review & \\
\hline TN & No Opinion & May be required \\
\hline
\end{tabular}

\subsection{Initial Analysis}

Our review of the 50 states and the District of Columbia indicates that four (4) states require DEs to have a license (Table 3). Sixteen (16) additional states have issued opinions that their statute would require a PI license to operate in that state (Table 4). Four (4) of those states indicated there were some limited exclusions to this opinion (Table 8). Four (4) states issued opinions that DEs are excluded (Table 5). Eight (8) states exclude DEs by statute (Table 6). Eight (8) states require no licensing of PIs or DEs (Table 7). The remaining states either did not respond (Table 9) to this year's survey or issued a no opinion on the matter (Table 10) for a total of eleven (11) states.

\section{RECOMMENDATIONS}

We would argue that it is not in the best interests of Digital Examiners, nor is it in the best interest of citizens, that DEs be licensed as Private Investigators. This is not to say that states should not license Digital Examiners, but rather should separate the two specializations into their respective parts. Digital Examiners have a specific role in investigations that does not overlap with those duties normally performed by Private Investigators. Conversely, the implication that PIs are capable of conducting DE investigations because they are licensed is harmful to all concerned.

Upon review of the requirements in various states it is often the case that PI licensing requires thousands of hours of apprenticeship as a PI or a law enforcement background. Neither of these skill sets necessarily intersects with that of DE. This prevents Digital Examiners from doing their job and thus denies 
citizens and organizations access to these individuals in those states or deprives those individuals of the right to work in those states.

These two investigative specializations rarely, if ever, converge. Thus, we recommend that states approach their regulation, licensing, and enforcement of Digital Examiners and Private Investigators as follows:

1) Adopt a clear definition of Digital Examiners.

2) Adopt a clear definition of Private Investigators.

3) Review certifications and determine which certifications are recognized by that state for the role of DEs.

4) Create a license for DE that is not governed by the PI board of the state. PI boards do not necessarily understand what is involved in DE practice. This board should be comprised of DE certified citizens holding vendor neutral certifications that include ethics policy and review, as well as regular recertification (e.g., Certified Computer Examiner type certifications [ISFCE, 2009]).

5) Barring the above, states should exclude DE from the requirement of a PI license much as they do forensic accountants, engineers, and others as per Rhode Island, Delaware, and others listed in Table 6.

\section{CONCLUSION}

We strongly encourage state constituents and practitioners to initiate action with their legislatures to implement the five (5) steps outlined above as well as to review professional recommendations such as ABA 301 (2009). Digital Examiners would, of course, be the best coalition to advocate for these changes. However, we would advocate a series of targeted educational materials first be made to inform DEs of their particular state's regulations and licensing because only a small fraction know whether PI licenses are obtainable, desirable, or relevant to their profession (White \& Micheletti, 2008). We also encourage Computer Forensic and other technology-related organizations to advocate for state regulatory and licensing changes.

Ultimately, we would argue that it is best to exclude Digital Examiners from an established Private Investigator licensing requirement, and rely on other professional certifications, such as the Certified Computer Examiner (ISFCE, 2012) or the GCFA (SANS, 2012). This ensures that citizens, state governments, and businesses have access to the most ethical and qualified individuals to conduct their forensics examinations and manage digital evidence.

\section{REFERENCES}

Addo Enterprises, Inc. (2009). PI State Licensing Requirements. Safety Basement. Retrieved from http://www.safetybasement.com/category_s/377.htm 
American Bar Association (ABA). (2009). Section of Science and Technology Law, 301. Retrieved from

http://www.abanet.org/leadership/2008/annual/recommendations/ThreeHundre dOne.doc

International Society of Forensic Computer Examiners (ISFCE) (2012). Certified Computer Examiner. Retrieved from http://www.certified-computerexaminer.com/

Kramer, J. (2009). Texas Government-mandated Computer Repair License Does Not Compute. Institute for Justice. Retrieved from http://www.ij.org/index.php?option=com_content\&task=view\&id=2189 \&Itemid $=129$

Lonardo, T., White, D., \& Rea, A. (2008). To License or Not to License: An Examination of State Statutes Regarding Private Investigators and Digital Examiners. The Journal of Digital Forensics, Security, and Law. 3(3).

Lonardo, T., White, D., \& Rea, A. (2009). To License or Not to License Revisited: An Examination of State Statutes Regarding Private Investigators and Digital Examiners. The Journal of Digital Forensics, Security, and Law, 4(3).

Mesis, J. (2011). Private Investigator License Requirements by State. Private Investigator Magazine. Retrieved from http://www.pimagazine.com/links_Licensing.htm

Rife vs. Texas Private Security Board. (2007). cTex. Occ. Code § 1702.381

SANS. (2012). GIAC Certified Forensics Analyst. Retrieved from http://www.giac.org/certifications /security/gcfa.php

White, D., Lonardo, T., \& Rea, A. (2012). pilaws. http://twitter.com/pilaws

White, D., \& Micheletti, C. (2008). Annual Survey of CCE Results. In Proceedings of the Decision Sciences Institute Conference. Baltimore, MD. November. 
Journal of Digital Forensics, Security and Law, Vol. 7(3) 